\title{
PELATIHAN CITIZEN JOURNALISM BAGI REMAJA USIA SEKOLAH SEBAGAI PENUNJANG PROMOSI PARIWISATA DI WILAYAH WILAYAH PESISIR PANTAI NAMBO DI KELURAHAN NAMBO, KECAMATAN ABELI
}

Bakri Yusuf ${ }^{1}$, Harnina Ridwan'2, Sirajuddin ${ }^{3}$, Masrul ${ }^{4}$

${ }^{1234}$ Fakultas Ilmu Sosial dan Ilmu Politik Universitas Halu Oleo

Jl. HEA Mokodompit No.1 Kampus Bumi Tridharma Anduonohu, Kendari 93232

\section{RINGKASAN}

Remaja usia sekolah di wilayah pesisir Pantai Nambo di Kelurahan Nambo, Kecamatan Abeli rata-rata menggunakan smartphone yang bisa terkoneksi dengan internet. Para remaja hampir semua menggunakan twitter, instagram dan facebook sebagai sarana yang memperlihatkan eksistensi dirinya dan membangun citra diri mereka. Saat ini pihak masyarakat di kelurahan tersebut memang membutuhkan adanya pelatihan atau workshop terkait pemanfaatan media internet guna menambah pengetahuan dan peningkatkan keterampilan remaja dalam penggunaan teknologi di bidang pariwisata. Kecanggihan teknologi akan berpengaruh terhadap kemajuan pariwisata, khususnya bidang promosi. Untuk itu dibutuhkan peran masyarakat termasuk remaja usia sekolah yang memiliki kompetensi dalam bidang pariwisata yang didukung dengan kemampuan memanfaatkan media internet sebagai wadah promosi. Olehnya itu, pengabdi berinisiatif untuk melakukan kegiatan pelatihan Citizen Journalism bagi remaja usia sekolah sebagai penunjang promosi pariwisata di wilyah pesisir wilayah pesisir Pantai Nambo di Kelurahan Nambo, Kecamatan Abeli yang bertujuan untuk (1) memberikan pemahaman kepada remaja usia sekolah tentang pemanfaatan internet sebagai media untuk mempromosikan potensi pariwisata. (2) memberikan pemahaman terkait optimalisasi media sosial dan pentingkan mempromosikan pariwisata melalui karya citizen journalism yang diunggah ke akun media online. Luaran yang diharapkan pada kegiatan Abdimas ini adalah para peserta mampu memahami Optimalisasi Pemanfaatan Media Online, kemudian peserta juga memiliki Keterampilan komunikasi (Public Relations) dalam menunjang bidang pariwisata yang pada akhirnya para peserta dapat memahami terkait citizen journalism sebagai penunjang dalam meningkatkan skill serta komunikasi peserta dalam promosi bidang pariwisata.Keempat, peserta akan menerima tentang pemanfaatan komunikasi Visual sebagai skill tambahan dalam kegiatan promosi partiwisata. Terakhir, peserta akan praktik membuat berita yang kemudian diunggah di akun sosial media peserta masing-masing.

Kata kunci: pelatihan; citizen journalism; remaja usia sekolah; pariwisata 


\section{A. Latar Belakang \\ 1. (Analisis Situasi)}

Saat ini, kecanduan internet telah menyerang tak hanya orang dewasa, melainkan pelajar bahkan anak-anak. Perkembangan zaman dan teknologi khususnya saat ini, telah memberi dampak yang tak sedikit terhadap perkembangan perilaku maupun pola pikir pelajar. Memang dapat dikatakan bahwa, jika para remaja usia sekolah mengenal dan menguasai teknologi (internet) sejak dini tentu lebih baik. Sebab di era digital saat ini teknologi akan berperan penting dalam memudahkan kehidupan manusia. Namun, menjadi hal mengkhawatirkan ketika internet disalahgunakan.

Kehadiran internet tentu dirasakan manfaat dan kegunaanya sejauh dipadang dan dimanfaatkan untuk hal-hal positif. Namun, tak dapat dipungkiri bahwa internet dengan informasi yang ada didalamnya, kerap menawarkan hal-hal yang menggiurkan, yang kadang menyimpang dari etika dan moral. Seiring berkembangnya waktu memanfaatkan fasilitas internet untuk berbagai tujuan pemenuhan kebutuhan. Berkat teknologi yang dikenal dengan internet, hampir semua kebutuhan manusia dapat diselesaikan mulai dari pemenuhan kebutuhan sehari-hari, bersosialisasi, mencari informasi sampai kepada pemenuhan kebutuhan hiburan (Hakim \& Raj, 2017: 280).

Hal yang sering tejadi dikalangan remaja usai sekolah setelah mengenal internet dan memasuki situs pertemanan yang ada di internet seperti Facebook, twitter, instagram dan sebagainya. Internet merupakan media yang menyajikan informasi apa saja yang dapat diakses semua orang dengan cara yang cepat dan mudah. Fenomena yang tejadi dikalangan remaja usia sekolah cenderung lebih nyaman berkomunikasi lewat internet ketimbang face to face. Teltyrkadang ia akan merasa lebih memiliki kedekatan dengan objek komunikasi melalui internet, daripada berkomunikasi langsung. Hal ini akan menyebabkan munculnya rasa sosial yang membuat seorang pelajar "mengisolasi diri". Terlebih pada jam belajar, ketika sebuah gadget di saku yang berbunyi, pelajar akan buru-buru melihatnya dan kemudian 
membalas komentar yang ada. Ditambah lagi internet juga menyebabkan rasa emosi menjadi kurang tajam dan mengakibatkannya tidak peka terhadap lingkungan. Game juga merupakan salah satu hiburan yang disajikan dalam internet. Merebaknya permainan internet dan beragamnya jenis permainan juga membuat para remaja menemukan arena bermain baru. Banyak jenis aplikasi permainan yang sangat mudah menarik perhatian para pecinta permainan, misalnya permainan yang menggunakan media internet contohnya (Salanity, dkk, 2015 : 2). Bahkan game juga memilki dampak negatif dan positif.

Remaja usia sekolah di wilayah pesisir Pantai Nambo di Kelurahan Nambo, Kecamatan Abeli yang berusia antara 16-18 tahun, sangat mudah terpengaruh oleh berbagai macam budaya, termasuk hal-hal negatif yang ada di internet. Sebagain besar pelajar ini telah mengenal internet sejak dini. Bahkan perilaku keseharian mereka tidak lepas dari internet melalui peralatan modern seperti laptop, gadget maupun smartphone. Beradasarkan survey awal, pelajar SMK Pariwisata Paramitha Bekasi rata-rata menggunakan smartphone yang bisa terkoneksi dengan internet. Para siswa hampir semua menggunakan twitter, instagram dan facebook sebagai sarana yang memperlihatkan eksistensi dirinya dan membangun citra diri mereka. Para siswa memposting foto-foto maupun video di media sosial bersama temantemannya yang memperlihatkan kebahagiaan dirinya. Sehingga dapat dikatakan bahwa individu menggunakan media sebagai representasi diri. Sangat disayangkan apabila remaja usia sekolah di wilayah pesisir Pantai Nambo di Kelurahan Nambo, Kecamatan Abeli yang mengunakan media online tidak diarahkan ke hal-hal yang positif yang tentu bermanfaat bagi lingkungan dimana mereka tinggal. usia sekolah di wilyah pesisir Pantai Nirwana Di Kelurahan Sulaa, Kecamatan Betoambari, Kota Baubau memiliki potensi yang dapat dikembangkan melalui penggunaan internet.

Berdasarkan uraian di atas, maka kami berinisiatif untuk memberikan pelatihan citizen journalism bagi remaja usia sekolah sebagai penunjang promosi pariwisata di wilayah pesisir Pantai Nambo di Kelurahan Nambo, Kecamatan Abeli 
Melalui pengenalan menjadi bagian dari Citizen Journalism, para remaja usia sekolahdapat berkontribusi dalam mengembangan bidang pariwisata baik ditingkat lokal, nasional maupun internasional.

\section{B. Identifikasi dan Perumusan Masalah (Permasalahan Mitra)}

Berdasarkan uraian situasi di atas, maka ada beberapa hal yang menjadi permasalahan yang perlu dipecahkan bersama yakni sebagai berikut:

1. Bagaimana pemanfaatan internet sebagai media untuk mempromosikan potensi pariwisata?

2. Bagaimana memberikan pemahaman kepada remaja usia sekolah sebagai penunjang promosi pariwisata di wilayah pesisir Pantai Nambo di Kelurahan Nambo, Kecamatan Abeli terkait optimalisasi media sosial dan pentingkan mempromosikan pariwisata melalui karya citizen journalism yang diunggah ke akun media online?

Penetuan permsalahan ini ditentukan atas dasar bahwa remaja usia sekolah sebagai penunjang promosi pariwisata di wilayah pesisir Pantai Nambo di Kelurahan Nambo, Kecamatan Abeli dominan menggunakan gadget, smartphone atau teknologi yang sejenis yang memungkinkan mereka terkoneksi dengan internet. Hal ini dapat dimanfaatkan untuk mempromosikan pariwisata melalui karya citizen journalism yang di unggah di media online.

\section{Tujuan Kegiatan}

Tujuan peneliti melakukan kegiatan pelatihan Citizen Journalism yakni:

1. Untuk memberikan pemahaman remaja usia sekolah sebagai penunjang promosi pariwisata di wilayah pesisir Pantai Nambo di Kelurahan Nambo, Kecamatan Abeli tentang pemanfaatan internet sebagai media untuk mempromosikan potensi pariwisata.

2. Untuk memberikan pemahaman remaja usia sekolah sebagai penunjang promosi pariwisata di wilayah pesisir Pantai Nambo di Kelurahan Nambo, Kecamatan Abeli, terkait optimalisasi media sosial dan pentingkan mempromosikan pariwisata melalui karya citizen journalism yang diunggah ke akun media online. 


\section{Target Luaran}

\subsection{Komponen Rencana Kegiatan}

Berdasarkan pada permasalahan yang dihadapi remaja usia sekolah sebagai penunjang promosi pariwisata di wilayah pesisir Pantai Nambo di Kelurahan Nambo, Kecamatan Abeli, dalam upaya meningkatkan kemampuan dan keterampilan dalam memanfaatkan media sosial.

\begin{tabular}{|c|c|c|}
\hline No & Jenis Luaran & Indikator Capaian \\
\hline 1 & $\begin{array}{lcc}\text { Peserta } & \text { mampu memahami } \\
\text { tentang } & \text { pemanfaatan media } \\
\text { internet } & \text { sebagai } & \text { wadah } \\
\text { promosi } & & \\
\end{array}$ & $\begin{array}{lrr}\text { Peserta pelatihan dapat } \\
\text { mengoptimalisasi pemanfaatan } \\
\text { Media internet } & \text { untuk } \\
\text { mempromosikan } & \text { potensi } \\
\text { pariwisata } & \end{array}$ \\
\hline 2 & $\begin{array}{l}\text { Peserta pelatihan memiliki skill } \\
\text { dalam berkomunikasi melalui } \\
\text { media internet }\end{array}$ & $\begin{array}{l}\text { Peserta pelatihan memiliki } \\
\text { keterampilan komunikasi (Public } \\
\text { Relations) dalam menunjang } \\
\text { profesionalitas siswa dalam bidang } \\
\text { pariwisata }\end{array}$ \\
\hline 3 & $\begin{array}{l}\text { Peserta pelatihan dapat } \\
\text { memahami pentingnya } \\
\text { promosi pariwisata melalui } \\
\text { karya citizen journalism yang } \\
\text { diunggah ke akun media } \\
\text { online. }\end{array}$ & 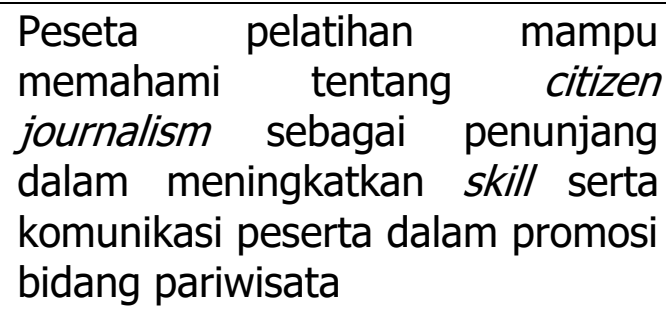 \\
\hline 4. & 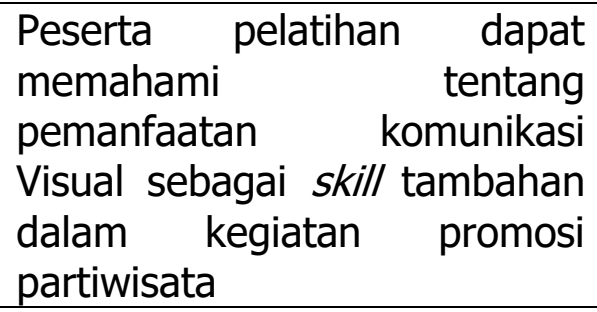 & $\begin{array}{l}\text { Peserta pelatihan mampu } \\
\text { mempromosikan pariwisata melalui } \\
\text { media visual }\end{array}$ \\
\hline
\end{tabular}

\section{E. Metode Pelaksanaan}

Berdasarkan kesepakatan dengan anggota mitra untuk meningkatkan kemampuan siswa dalam menyusun berita yang akan diunggah media online guna menunjang aktivitas promosi pariwisata, maka pengusul proposal menggunakan 
metode pendekatan dengan kegiatan Pelatihan dalam pengabdian kepada masyarakat ini. Pelatihan akan dilaksanakan dalam dua tahap yakni teori dan praktek atau penerapannya yang berupa contoh-contoh kegiatan postif dalam memanfaatkan media online, praktik penyusunan berita yang kemudian di unggah di akun media online peserta dan sebagainya. Pada kegiatan pertama, peserta pelatihan akan menerima materi mengenai Optimalisasi Pemanfaatan Media Online.

\section{F. Realisasi Kegiatan}

Kegiatan pengabdian pelatihan citizen journalism bagi remaja usia sekolah sebagai penunjang promosi pariwisata wilayah pesisir Pantai Nambo di Kelurahan Nambo, Kecamatan Abeli selama 1 hari pada tanggal 30 April 2019. Peserta yang mengikuti kegiatan ini berjumlah 30 orang yang terdiri dari para remaja uia sekolah

Kegiatan pada sesi pertama diawali dengan memberikan ceramah kepada para peserta penyulihan untuk menjelaskan tentang jurnalistik praktis sebagai penunjang promosi pariwisata, dilanjutkan dengan sesi kedua yang merupakan sesi tanya-jawab/ diskusi dimana para peserta terlihat antusias untuk saling bertukar pikiran dan mengutarakan masalahnya masing-masing serta saling memberikan solusi atas permasalahan yang disampaikan.

\section{Hasil yang dicapai:}

Kegiatan ini telah berhasil mencapai tujuan yang diharapkan karena para peserta pelatihan telah mampu memahami mengenaiteori-teori jurnalistik dan teknik-teknik melakukan wawancara dan membuat berita. Mulai dari berita jenis straight news maupun feature news sebagai penunjang promosi pariwisata,

\section{G. Faktor Pendukung dan Penghambat}

Kegiatan ini dapat terlaksana dengan lancar karena didukung oleh beberapa faktor, yakni; (a) adanya dukungan dari masyarakat dan phak pemeintah kelurahan setempat dengan menyiapkan tempat atau ruangan sebagai tempat pelaksanaan penyuluhan, (b) tingginya motivasi para siswa selaku peserta dalam mengikuti kegiatan ini, (c) adanya kerjasama tim sejak persiapan hingga waktu pelaksanaan kegiatan ini. 
Adapun yang menjadi faktor penghambat dari kegiatan ini adalah waktu pelaksanaan yang relatif singkat. Hal ini membuat waktu untuk melaksanakan sesi tanya jawab dan diskusi menjadi terbatas, apalagi mengingat banyaknya pertanyaan dan respon dari para peserta pelatihan. Namun demikian, kegiatan ini dinilai telah memberikan hasil yang memuaskan dengan pencapaian target yang sangat memuaskan.

\section{H. Kesimpulan Dan Saran}

\section{Kesimpulan}

Kegiatan pengabdian berupa pengabdian pelatihan citizen journalism bagi remaja usia sekolah sebagai penunjang promosi pariwisata di wilyah wilayah pesisir Pantai Nambo di Kelurahan Nambo,Kecamatan Abeli initelah mampu meningkatkan pengetahuan, pemahaman dan keterampilan para peserta. Dengan begitu kemampuan dan keterampilan para siswa diharapkan akan meningkat. Keberhasilan kegiatan ini juga terlihat dari sesi kedua yang merupakan sesi tanya-jawab/ diskusi dimana para peserta terlihat antusias untuk saling bertukar pikiran dan mengutarakan masalahnya masingmasing serta saling memberikan solusi atas permasalahan yang disampaikan.

\section{Saran}

Diharapkan kepada para peserta yang telah mengikuti kegiatan agar senantiasa melatih dan mengembangkan kemampuan dirinya di bidang jurnalistik, diantaranya kemampuan wawancara dan menulis berita. Hal ini tentunya perlu dilakukan agar pengetahuan dan keterampilan yang telah diperoleh dalam pelatihan ini dapat bermanfaat utamanya dapat meunjang promosi pariwisata terutama diwilayah wilayah pesisir Pantai Nambo di Kelurahan Nambo, Kecamatan Abeli

\section{DAFTAR PUSTAKA}

Hakim, Sitti N. \& Raj Aliffatullah. 2017. Dampak Kecanduan Internet (Internet Addiction) pada Remaja. Prosiding Temu Ilmiah X Ikatan Psikologi Perkembangan Indonesia; Peran Psikologi Perkembangan dalam pertumbuhan Humanitas pada Era Digital. ISBN: 978-602-1145-49-4. 
Kusmayadi. 2000. Peluang Pengembangan Kerja Bidang Pariwisata (Studi Kasus DIY, Bali dan NTB). Jurnal Ilmu Pariwisata. Vol 4, No.3 Mei. ISSN: 1411-1527.

Sukartik. 2016. Peran Jurnalisme Warga Dalam Mengakomodir Aspirasi Masyarakat. Jurnal RISALAH, Vo.27, No.1, Juni 2016; 10-16.

Salanity, Falyana R; Walandow A; Rondonuwu S. 2015. Pengaruh Permainan Internet Terhadap Perilaku Remaja di Keluarahan Karombasan Utara. Journal 'Acta Diurna" Volume Iv. No.1 Tahun 2015. Hal. 1 - 12. 